\title{
Low faunal diversity on Maltese sandy beaches: fact or artefact?
}

\author{
Alan Deidun, Marthese Azzopardi, Stephen Saliba, Patrick J. Schembri* \\ Department of Biology, University of Malta, Msida MSD06, Malta
}

Received 23 October 2001; accepted 31 July 2002

\begin{abstract}
Eight sandy beaches on Malta and two on Gozo were sampled for macrofauna to test the hypothesis that Maltese beaches have an intrinsically low diversity. Stations distributed in the supralittoral (dry zone), mediolittoral (wet zone) and upper infralittoral (submerged zone to $1 \mathrm{~m}$ water depth) were sampled by sieving core samples and standardised searching during daytime, and pitfall trapping and standardised sweeping of the water column using a hand-net at night, as appropriate. Physical parameters of the sediment were measured and human occupancy of the beaches was estimated.

From the supralittoral and mediolittoral, 39 species represented by 1584 individuals were collected by the combined techniques of pitfall trapping, sieving and standard searching. For Ramla beach, which had the highest diversity, 267 individuals representing 25 infaunal species were collected by sieving from a combined volume of $1.175 \mathrm{~m}^{3}$ of sand, and 149 individuals representing 28 epifaunal species were collected by standardised searching from a combined area of $700 \mathrm{~m}^{2}$ of sand during two winter and two summer sampling sessions between 1992 and 1993. For nine other beaches sampled during the summer of 2000, only six macrofaunal species were collected from core samples, with overall population densities ranging from 4.13 to 45.45 individuals $\mathrm{m}^{-2}$. Only 92 individuals belonging to 12 species were collected by hand-net from the uppermost infralittoral of five beaches sampled using this method during the summer of 2000. Taxa of gastropods, bivalves, decapods, mysids and staphylinid beetles generally abundant on Mediterranean sandy beaches, were entirely absent from the beaches sampled.

Few correlations that could explain the impoverishment of Maltese sandy beaches were found between physical parameters and faunal abundances, and other factors such as inadequate sampling effort, human disturbance and marine pollution were also excluded; however, seasonally biased sampling may partly explain the results obtained. One factor that may explain why certain species are missing could be lack of recruitment, due to Malta's geographical isolation from the European and African mainlands.
\end{abstract} (C) 2003 Elsevier Ltd. All rights reserved.

Keywords: sandy beaches; macrofauna; diversity; faunal impoverishment; benthos; Malta; Mediterranean

\section{Introduction}

Sandy beaches comprise only ca $2.4 \%$ of the Maltese coastline, which has a total length of $190 \mathrm{~km}$ (Axiak et al., 1999). This makes such habitats rather rare locally. Moreover, tourism is very important for the economy of the islands and sandy beaches are much sought after by tourists. They are also a valuable recreational resource for the local populace. As might be expected therefore,

\footnotetext{
* Corresponding author.

E-mail address: patrick.j.schembri@um.edu.mt (P.J. Schembri).
}

there is tremendous human pressure on sandy beach habitats and some such habitats (for example, sand dunes) are severely threatened, while a number of associated species are among the most endangered of the local biota.

Given this situation it is perhaps surprising that general information on the ecology of Maltese sandy beaches is very scarce. Practically the only information available to date is a number of dissertations, some species lists based mainly on casual collection (Hili, Lanfranco, \& Schembri, personal communication), and reports on coastal zone surveys commissioned by Government agencies, all of which are unpublished. However, this situation is not unique in a regional 
context, as very few studies on the ecology of southern Mediterranean shores have been made (Charfi-Cheikhrouha, Bouslama, \& ElGtari, 2001; Colombini, Fallaci, Milanesi, Scapini, \& Chelazzi, 2003; Dexter, 1986/1987, 1989; Marques et al., 2003). Indeed Dexter (1992) cites northern Africa, together with the western Pacific Ocean, tropical South America and the Arabian coasts, as regions where sandy beaches have not been adequately studied. Moreover, few of these Mediterranean studies concern sandy beach fauna as a whole, as many relate to the ecology of individual species, as for example the studies by Charfi-Cheikhrouha et al. (2001) and Marques et al. (2003) which concern talitrid amphipods.

Compared to rocky or muddy intertidal habitats, sandy beaches are intrinsically poor in biota; in general, on sandy beaches there is a high diversity of different species of organisms living in the sediment, but not a high biomass (Abele, 1976), although for insects, species richness increases landwards up the beach whereas abundance decreases (e.g. McLachlan, 1991). However, the few studies that have been made on Maltese beaches (e.g. Sammut, personal communication) indicate that these are remarkably poor, both in terms of species richness and abundance. Thus, for the beach at Ramla in Gozo, Sammut only found an overall population density of ca 150 individuals $\mathrm{m}^{-2}$ for epifauna and ca 270 individuals $\mathrm{m}^{-3}$ in the upper $30 \mathrm{~cm}$ of sand for infauna, for all species considered together. This study included the entire beach area from the foredunes to mean sea level.

Mediterranean sandy beaches as a whole are known for their low biotic diversity. Dexter (1986/1987) reports the Mediterranean beaches of Egypt to be almost barren both in terms of individuals and in number of species, and she estimated an intertidal density of less than 10 individuals $\mathrm{m}^{-2}$, although these observations must be viewed in the light of the notoriously impoverished biota of the eastern Mediterranean (Por, 1978). The question therefore arises as to whether Maltese sandy beaches are really as impoverished as preliminary studies suggest or whether this apparent impoverishment is an artefact of inadequate sampling, and secondly, whether Maltese sandy beaches are any poorer than other similar habitats in the region.

The present study, therefore, had two principal aims. First, since little work has been carried out on the ecology of Maltese sandy beach assemblages, more baseline information on community structure, zonation patterns and faunal abundances needed to be collected for these ecosystems. The second aim was to confirm or otherwise the hypothesis that Maltese beaches have an intrinsically low diversity, and if this hypothesis is supported, to investigate why.

The beaches investigated in the present study were chosen for a variety of reasons. Ramla has the best preserved sandy beach/sand dune system in the Maltese
Islands, while White Tower Bay, although degraded, still has a relatively thriving sandy beach ecosystem. Gnejna, Paradise Bay and Ghadira were chosen in view of their great popularity with locals and tourists alike and are therefore good examples of beaches that experience elevated levels of human disturbance. The beaches at Ix-Xatt 1-Ahmar, Small Bay and Qarraba were chosen for the opposite reason-due to their relative inaccessibility, they are not as frequented by visitors and may serve as partial controls in investigating the relationship between human use of beaches and beach faunal abundances.

\section{Methods}

The location of the beaches studied is shown in Fig. 1. At Ramla, standard searches were used to collect mobile epifauna. These consisted of an observer walking for $10 \mathrm{~min}$ along a shore-normal line transect while searching for and recording all organisms encountered on the surface of the sand. Box-cores were used to collect infauna. A box-corer of area $0.15 \mathrm{~m} \times 0.15 \mathrm{~m}$ was pushed into the sand and the top $10 \mathrm{~cm}$ of sand were transferred to a $0.5 \mathrm{~mm}$ mesh sieve and wet sieved in seawater. The same procedure was repeated for the sand fractions between 10 and $20 \mathrm{~cm}$ and between 20 and $30 \mathrm{~cm}$ below the beach surface. Samples were taken every $5 \mathrm{~m}$ along transects varying in length between 40 and $70 \mathrm{~m}$, so that a total of $1.175 \mathrm{~m}^{3}$ was sieved. Ramla is practically the only beach in the Maltese Islands with a relatively intact dune system and here the standard searches and core sampling were carried out from mean sea level up to the foredune zone.

For the other sandy beaches at White Tower Bay, Gnejna and Ix-Xatt 1-Ahmar, the same sampling techniques as for Ramla were used, however, on these beaches only the supralittoral and upper infralittoral regions were studied-i.e. from mean sea level to the limit of vegetation-free sand. Transects were divided into wet and dry zones and the strandline was taken as delineating the boundary between the two. Standard searches were made within $5 \mathrm{~m} \times 3 \mathrm{~m}$ rectangles, one in the wet and one in the dry zone of each transect. For the same beaches and for the beaches at Golden Bay, Paradise Bay, Qarraba, Ghadira, Small Bay and Ghajn Tuffieha, core samples were also collected from the lower mediolittoral and uppermost infralittoral of the beach-i.e. from the surf zone to the submerged bottom down to a water depth of $1 \mathrm{~m}$.

Pitfall traps were used on selected beaches (Ramla, White Tower Bay, Gnejna and Ix-Xatt 1-Ahmar) to collect sand fauna that burrows during the day and only emerges at night. The traps consisted of five $7.5 \mathrm{~cm}$ diameter plastic cups inserted into the sand such that their mouth was flush with the sand surface. The cups 


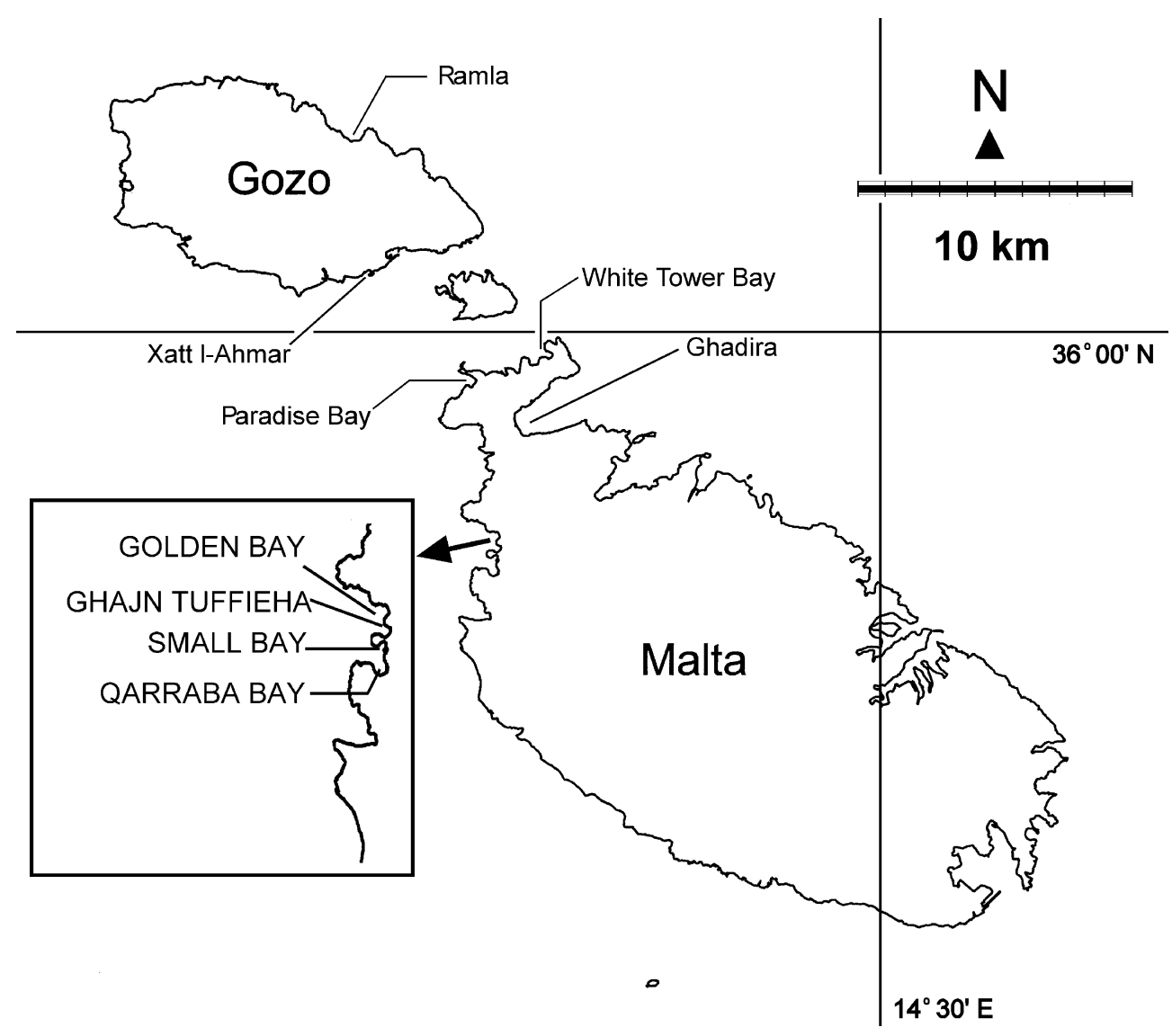

Fig. 1. Map of the Maltese Islands showing the location of the beaches studied. The inset shows the beaches at Golden Bay, Ghajn Tuffieha, Qarraba Bay and Small Bay, which are located within a few hundred metres of each other.

where arranged one at the centre and the other four in a cross-pattern and the peripheral traps were connected to the central one by thin strips of wood resting on the sand, which served as walk-ways; the use of such walkways greatly enhances sampling efficiency (Chelazzi, personal communication). Constellations of five cups each were placed in the dry and wet zones of each transect after midnight (to reduce disturbance by human beach users) and were emptied in the morning, $5 \mathrm{~h}$ later.

Night-time standardised collecting using a hand-net of mouth area $0.097 \mathrm{~m}^{2}$ and mesh size $0.5 \mathrm{~mm}$ was used in the uppermost regions of the infralittoral zone (water ca $1 \mathrm{~m}$ deep) of five beaches (Ramla, Ghadira, Golden Bay, Ghajn Tuffieha and Qarraba). The net was swept gently from side to side for $20 \mathrm{~min}$ as the handler slowly walked parallel to the shore along each beach. This sampling technique was designed to collect upper infralittoral burrowing infauna that emerged to swim in the water column at night.

The grain-size distribution of the beach sediment was determined for all beaches studied using the method described by Buchanan (1984), and median distribution, and sorting were estimated. The percentage organic content of the sediment was determined using the Walkley and Black titration method following wet- oxidation by potassium dichromate, as described by Buchanan (1984) and Morgans (1956). The physically derived exposure index proposed by Thomas (1986) was used to determine the exposure to wave action experienced by each beach. The length of the beaches studied was determined from survey sheets. Tidal data were obtained from the tables by Drago and Xuereb (1993); the maximum spring tidal range is ca $20 \mathrm{~cm}$. No wave height data are available.

For Ramla, White Tower Bay, Gnejna and Ix-Xatt 1-Ahmar, temperature, percentage water content, $\mathrm{pH}$ and salinity of the sand were measured. Temperature was measured by inserting a thermometer to a depth of $5 \mathrm{~cm}$ below the sand surface, while the percentage water content was determined from the dry weight of sediment samples after heating to constant weight at $90^{\circ} \mathrm{C}$. Salinity and $\mathrm{pH}$ of the interstitial water in sediment samples were determined in the laboratory using conductivity and $\mathrm{pH}$ probes, respectively. The depth at which the anoxic sand layer occurred was recorded in the field and the beach slope profile was measured using the method described by Eifion Jones (1980). In addition, human beach occupancy was estimated for selected beaches by taking standardised counts. This was done by taking photographs of a defined area of each beach at 
peak occupancy time $(13: 00 \mathrm{~h})$ from the same vantage point at monthly intervals during the period JulySeptember and then counting the number of occupants in the defined area from the photographic images.

Species-area curves were plotted for those beaches where the data set was sufficiently large to test the adequacy of the sampling effort (i.e. for sieving and standard searches). Comparison of physical parameters between different beaches was made using ANOVA at 0.05 significance. Any possible correlations between the number of individuals and the number of species collected, and the organic content, water content, $\mathrm{pH}$, salinity, median particle diameter and the silt-clay fraction of the four beaches for which these data were available, were investigated using linear regression.

Similarity in the faunal assemblages of the different beaches was studied by cluster analysis using the Jaccard similarity index based on presence/absence data only, since different sampling techniques were used to collect fauna. The resultant dendrograms are shown in Fig. 2. The SPSS (Norusis, 1993), BMDP (Dixon, 1988) and PRIMER (Plymouth Routines in Multivariate Ecological Research; Clarke \& Warwick, 1994) suite of programs were used for the statistical analyses.
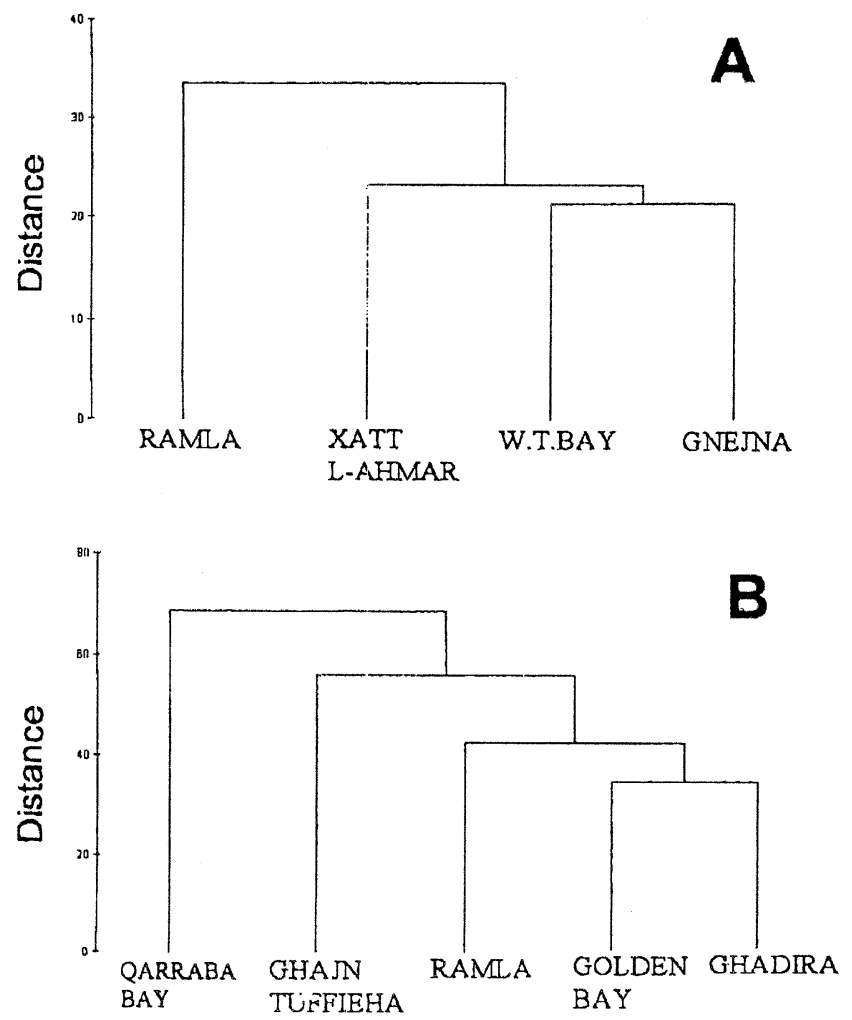

Fig. 2. Dendrograms resulting from cluster analysis of faunal presence/absence data for (A) the supralittoral zone and (B) the infralittoral zones of the beaches sampled, using the Jaccard similarity index and agglomerative group-average linkage.

\section{Results}

Table 1 gives the physical characteristics of the beaches studied. Of the 10 beaches studied, seven can be considered to have low exposure (Thomas exposure index $<6.5$ ), while three - Ghadira, Ghajn Tuffieha and Golden Bay - were quite exposed (Thomas exposure index 9.3-12.9; for comparison, the shore with the highest exposure in the Maltese Islands, that at San Dimitri in Gozo, has a Thomas exposure index value of 34.5).

A total of 267 individuals representing 25 infaunal species were collected by sieving from the beach at Ramla from a combined volume of $1.175 \mathrm{~m}^{3}$ of sand during two winter and two summer sampling sessions between 1992 and 1993. The population density ranged from 18 to 70 individuals $\mathrm{m}^{-2}$, while the number of species ranged from 2 to 9 species $\mathrm{m}^{-2}$. A total of 149 individuals representing 28 epifaunal species were collected from the same beach by standardised searching from a combined area of $700 \mathrm{~m}^{2}$ of sand during the same sampling seasons. The population density ranged from 0.05 to 0.68 individuals $\mathrm{m}^{-2}$ and the number of species ranged from 0.03 to 0.18 species $\mathrm{m}^{-2}$.

During sampling in the supralittoral and mediolittoral of the beaches at Ramla, White Tower Bay, Gnejna and Ix-Xatt 1-Ahmar in the summer of 2000, 1474 individuals were collected in pitfall traps, 74 were collected by standardised searching, while 36 (not including coleopteran larvae) were collected by sieving core samples. The total number of species collected by the three techniques together was 39 (Table 2). Overall population densities for pitfall trap, sieving and search collections ranged between 45 individuals trap ${ }^{-1}$ at Xatt 1-Ahmar and 276.36 individuals $\operatorname{trap}^{-1}$ at Ramla, between 6 individuals $\mathrm{m}^{-3}$ at Gnejna and 261 individuals $\mathrm{m}^{-3}$ at Ramla, and between 0.51 individuals $\mathrm{m}^{-2}$ at Xatt L-Ahmar and 0.85 individuals $\mathrm{m}^{-2}$ at White Tower Bay, respectively.

During sampling in the lower mediolittoral and uppermost infralittoral of the beaches at Ghajn Tuffieha, Golden Bay, Ghadira, Qarraba, Paradise Bay, Gnejna, Small Bay, Ramla and White Tower Bay in the summer of 2000, only six macrofaunal species were collected from the core samples with overall population densities ranging from 4 individuals $\mathrm{m}^{-2}$ at Golden Bay to 45 individuals $\mathrm{m}^{-2}$ at Ghadira; for five of these beaches, no macrofauna at all was collected (Table 3). Only 92 individuals belonging to 12 species were collected by hand-net from the uppermost infralittoral of the five beaches sampled using this method (Table 3), with overall population densities ranging from 0.6 individuals $\mathrm{m}^{-2}$ at Qarraba to 21 individuals $\mathrm{m}^{-2}$ at Ghadira. The total number of species collected by the two techniques in the mediolittoral and uppermost infralittoral was 16 .

Water content values for the beaches at White Tower Bay, Ramla, Gnejna and Ix-Xatt 1-Ahmar ranged from 


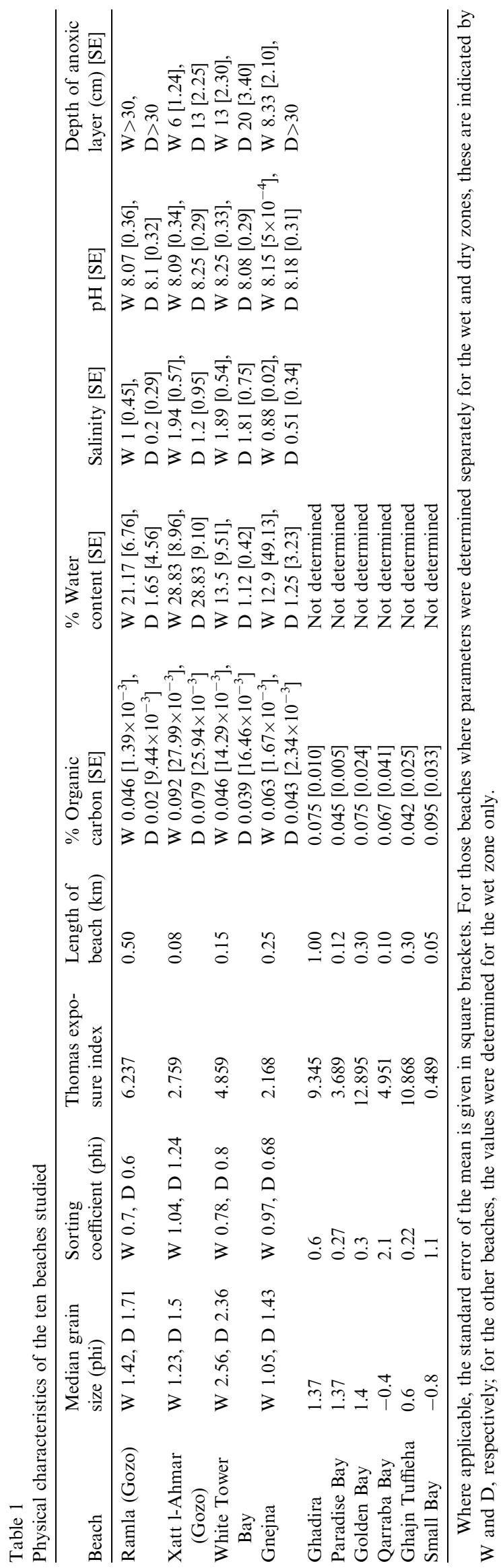

1.12 to $6.96 \%$ for the dry zones and from 12.96 to $28.83 \%$ for the wet zones. For the same zones, organic carbon content ranged from 0.023 to $0.079 \%$ and from 0.046 to $0.092 \%$, respectively, $\mathrm{pH}$ ranged from 8.08 to 8.25 and from 8.09 to 8.25 , respectively, and salinity ranged from 0.51 to 1.51 and from 0.88 to 1.94 , respectively. On the basis of the grain-size parameters measured, the sand at White Tower Bay and Qarraba was classified as fine, that at Gnejna, Ramla, Ghajn Tuffieha, Golden Bay, Ix-Xatt 1-Ahmar and Paradise Bay was classified as medium, while that at Small Bay was classified as coarse. The silt-clay fraction (the fraction $<63 \mu \mathrm{m}$ ) was generally unimportant for all beaches, with values never exceeding $0.92 \%$.

The beach occupancy rates for the beaches at White Tower Bay, Ramla, Gnejna and Ix-Xatt 1-Ahmar ranged from 0.0024 people $\mathrm{m}^{-2}$ (at Ramla) to 0.0123 people $\mathrm{m}^{-2}$ (at Gnejna). The slope for the same beaches ranged from $0.207^{\circ}$ (at White Tower Bay) to $8.550^{\circ}$ (at Ramla).

The only significant correlation between the number of individuals and/or species collected and beach wet zone physical characteristics was a negative one $(r=-0.998 ; P<0.05)$ between the number of species collected per square metre by standardised searching and the water content.

For the dry zone, significant positive correlations were found between the number of individuals $\mathrm{m}^{-2}$ collected by sieving and salinity $(r=1.000 ; \quad P<0.01)$, and between the number of species $\mathrm{m}^{-2}$ collected by sieving and salinity $(r=1.000 ; \quad P<0.05)$, while significant negative correlations were found between pitfall trap faunal abundances and salinity $(r=-1.000, P<0.05)$ and between the number of species $\mathrm{m}^{-2}$ collected by standardised searching and $\mathrm{pH}(r=-0.999 ; P<0.05)$.

Exposure to wave action was significantly positively correlated with the overall (i.e. wet and dry zones taken together) number of species $\mathrm{m}^{-3}$ of sand sieved $(r=$ 0.998; $P<0.05)$ only. No significant correlations were found between beach occupancy rates or grain-size parameters and faunal abundances for any of the three sampling techniques used.

Cluster analysis showed that for the supralittoral, White Tower Bay and Gnejna were marginally more similar than the other beaches, however, none of the four beaches were really very similar (Fig. 2A). The dissimilarity between beaches was even more pronounced for the mediolittoral and upper infralittoral (Fig. 2B).

\section{Discussion}

The vast majority of supralittoral and mediolittoral fauna collected consisted of burrowing, nocturnally active forms; $85.95 \%$ of all individuals collected from Gnejna, $72.66 \%$ from White Tower Bay and 84.72\% from Ix-Xatt 1-Ahmar were collected by pitfall traps. 
Table 2

Abundance of the species collected from the supralittoral and upper mediolittoral zones of the beaches studied, using three different techniques: (A) core sampling; (B) standard search and (C) pitfall trapping

\begin{tabular}{|c|c|c|c|c|}
\hline \multirow[b]{2}{*}{ Species } & \multicolumn{4}{|l|}{ Beach } \\
\hline & Ramla & White Tower Bay & Xatt 1-Ahmar & Gnejna \\
\hline \multicolumn{5}{|l|}{ (A) Core samples (individuals $\mathrm{m}^{-3}$ ) } \\
\hline Allophylax picipes melitensis [C] & * & $*$ & $*$ & W 0, D 0.56 \\
\hline Ammobius rufus $[\mathrm{C}]$ & * & $*$ & W 0, D 2.23 & $*$ \\
\hline Anthicus sp. [C] & * & * & $*$ & W 0, D 0.56 \\
\hline Phaleria acuminata $[\mathrm{C}]$ & W 0, D 5.45 & $*$ & W 0, D 2.23 & W 0, D 1.67 \\
\hline Trachyselis aphodioides [C] & W 0, D 4.04 & W 2.87, D 10.03 & $*$ & W 0, D 1.12 \\
\hline Berosus sp. $[\mathrm{C}]$ & $*$ & $*$ & W 0, D 2.23 & W 0, D 0.56 \\
\hline Bembix oculata $[\mathrm{H}]$ & * & * & W 0, D 4.46 & $*$ \\
\hline Labidura riparia $[\mathrm{D}]$ & * & * & W 0, D 1.12 & $*$ \\
\hline Tethina ochracea $[\mathrm{D}]$ & $*$ & $*$ & $*$ & W 0, D 0.56 \\
\hline Idotea basteri $[\mathrm{I}]$ & W 0, D 93.62 & * & * & $*$ \\
\hline Ligia italica $[\mathrm{I}]$ & * & W 2.87, D 0 & * & * \\
\hline Ophelia bicornis $[\mathrm{P}]$ & W $157.78, \mathrm{D} 0$ & $*$ & $*$ & $*$ \\
\hline \multicolumn{5}{|c|}{ (B) Standard search (individuals $m^{-2}$ ) } \\
\hline Phaleria acuminata $[\mathrm{C}]$ & W 0, D 0.04 & W 0, D 0.02 & $*$ & W 0, D 1.67 \\
\hline Trachyselis aphodioides [C] & W 0, D 0.03 & W 0, D 0.14 & $*$ & W $0, \mathrm{D} 1.12$ \\
\hline Ammobius rufus $[\mathrm{C}]$ & W 0, D 0.02 & $*$ & W 0.08, D 0 & $\mathrm{~W} 0.09, \mathrm{D} 0$ \\
\hline Anthicus sp. [C] & W 0, D 0.03 & * & $*$ & $*$ \\
\hline Histeridae sp. A [C] & W 0, D 0.04 & $*$ & * & W 0, D 0.01 \\
\hline Tapinoma simrothi $[\mathrm{H}]$ & $\mathrm{W} 0, \mathrm{D} 0.03$ & $\mathrm{~W} 0, \mathrm{D} 0.03$ & $*$ & $*$ \\
\hline Camponotus barbaricus $[\mathrm{H}]$ & W 0, D 0.03 & W 0, D 0.43 & $*$ & W 0.04, D 0.27 \\
\hline Polistes omissus $[\mathrm{H}]$ & $*$ & W 0.08, D 0 & W 0.06, D 0 & W 0.12, D 0.05 \\
\hline Pompilidae sp. B $[\mathrm{H}]$ & W 0, D 0.04 & $*$ & $*$ & $*$ \\
\hline Bembix oculata $[\mathrm{H}]$ & $*$ & $*$ & W 0, D 0.2 & $\mathrm{~W} 0.01, \mathrm{D} 0.04$ \\
\hline Sphecidae sp. A $[\mathrm{H}]$ & * & W 0 ,D 0.01 & $*$ & * \\
\hline Aiolopus strepens $[\mathrm{O}]$ & * & $*$ & W 0, D 0.04 & $*$ \\
\hline Brachynema cinctum $[\mathrm{Ht}]$ & * & $*$ & W 0, D 0.01 & $*$ \\
\hline Tethina ochracea $[\mathrm{Di}]$ & * & W 0, D 0.01 & $*$ & W 0, D 0.01 \\
\hline Fucellia tergina $[\mathrm{Di}]$ & * & W 0, D 0.01 & $*$ & $\mathrm{~W} 0, \mathrm{D} 0.01$ \\
\hline Craticulina sp. [Di] & * & $*$ & W 0.09, D 0.03 & $\mathrm{~W} 0.07, \mathrm{D} 0$ \\
\hline Ligia italica $[\mathrm{I}]$ & $*$ & $\mathrm{~W} 0.02, \mathrm{D} 0$ & $\mathrm{~W} 0.02, \mathrm{D} 0$ & $\mathrm{~W} 0.01, \mathrm{D} 0$ \\
\hline Idotea basteri $[\mathrm{I}]$ & W 0, D 0.02 & $*$ & $*$ & * \\
\hline Orchestia stephenseni $[\mathrm{A}]$ & $*$ & W 0.01, D 0 & $\mathrm{~W} 0.07, \mathrm{D} 0$ & $*$ \\
\hline Talitrus saltator ? $[\mathrm{A}]$ & * & $\mathrm{W} 0.08, \mathrm{D} 0$ & $\mathrm{~W} 0.09, \mathrm{D} 0$ & $\mathrm{~W} 0.05, \mathrm{D} 0$ \\
\hline \multicolumn{5}{|c|}{ (C) Pitfall traps (individuals per trap per unit catching effort) } \\
\hline Allophylax picipes melitensis $[\mathrm{C}]$ & W 0.5, D 0.67 & $*$ & $*$ & $*$ \\
\hline Phaleria acuminata $[\mathrm{C}]$ & W $54, \mathrm{D} 67.5$ & $\mathrm{~W} 2.5, \mathrm{D} 2$ & W 80, D 63.7 & $\mathrm{~W} 0.5, \mathrm{D} 28.5$ \\
\hline Anthicus sp. $[\mathrm{C}]$ & $\mathrm{W} 0.5, \mathrm{D} 0$ & W 0, D 0.5 & $*$ & $*$ \\
\hline Phaleria bimaculata $[\mathrm{C}]$ & $*$ & W 20.5 , D 7 & $*$ & $*$ \\
\hline Siagona sp. $[\mathrm{C}]$ & * & $*$ & W 0, D 0.67 & * \\
\hline Alleculidae sp. A [C] & $*$ & W $1, \mathrm{D} 0$ & $*$ & * \\
\hline Formicidae $[\mathrm{H}]$ & $\mathrm{W} 2.5, \mathrm{D} 20$ & W 0, D 3.5 & $*$ & $*$ \\
\hline Camponotus barbaricus $[\mathrm{H}]$ & W $2.5, \mathrm{D} 0.67$ & W $0, \mathrm{D} 1.5$ & $*$ & W 0, D 15.5 \\
\hline Messor structor $[\mathrm{H}]$ & W 0, D 1.33 & W $0, \mathrm{D} 1.5$ & W 0, D 1.33 & W 0, D 4 \\
\hline Ctenolepisma longicaudata $[\mathrm{Z}]$ & W $0, \mathrm{D} 1.67$ & W 0, D 0.5 & W 2, D 0 & $*$ \\
\hline Labidura riparia $[\mathrm{D}]$ & W 1, D 18 & $\mathrm{~W} 2.5, \mathrm{D} 0$ & W $2.67, \mathrm{D} 4.33$ & W 0.5, D 3.5 \\
\hline Nysius graminicola, $[\mathrm{Ht}]$ & $*$ & W 0.5, D 0 & $*$ & $*$ \\
\hline Ant-Lion Larvae $[\mathrm{N}]$ & $*$ & $*$ & W 0, D 3 & \\
\hline Armadillium vulgare $[\mathrm{I}]$ & W 0, D 0.67 & $*$ & $*$ & $*$ \\
\hline Tylos europaeus $[\mathrm{I}]$ & * & * & W 106.33 , D 3 & $*$ \\
\hline Ligia italica $[\mathrm{I}]$ & $*$ & $*$ & * & $\mathrm{W} 0.5, \mathrm{D} 1$ \\
\hline Talitrus saltator ? [A] & W 3.5, D 1 & W 5, D 1.5 & W 7, D 2.33 & W 3.5, D 1.5 \\
\hline Orchestia stephenseni $[\mathrm{A}]$ & $*$ & $*$ & $*$ & $\mathrm{~W} 2.5, \mathrm{D} 0$ \\
\hline Europyis acuminata $[\mathrm{Ar}]$ & * & $\mathrm{W} 0.5, \mathrm{D} 0$ & $*$ & $*$ \\
\hline Lycosidae $[\mathrm{Ar}]$ & * & W $0, \mathrm{D} 1.5$ & $*$ & * \\
\hline
\end{tabular}

Abundances in the wet and dry zones of the each beach are indicated by $\mathrm{W}$ and $\mathrm{D}$, respectively. An asterisk indicates that no individuals were collected from either wet or dry zones. [A] Amphipoda, [Ar] Araneae, [C] Coleoptera, [D] Dermaptera, [Di] Diptera, [H] Hymenoptera, [Ht] Heteroptera, [I] Isopoda, [N] Neuroptrera, [O] Orthoptera, [P] Polychaeta and [Z] Zygentoma. 
Table 3

Abundance of the species collected from the lower mediolittoral and uppermost infralittoral (from mean sea-level to a water depth of $1 \mathrm{~m}$ ) for beaches studied, using two different techniques: (A) core sampling and (B) standardised collecting using a hand-net

\begin{tabular}{|c|c|c|c|c|c|}
\hline \multirow[b]{2}{*}{ Species } & \multicolumn{5}{|l|}{ Beach } \\
\hline & Ramla & Golden Bay & Ghadira & Qarraba & Ghajn Tuffieha \\
\hline \multicolumn{6}{|c|}{ (A) Core sampling (individuals $m^{-3}$ ) } \\
\hline Ophelia bicornis $[\mathrm{P}]$ & 15.34 & 0 & 0 & 0 & \\
\hline Nematonereis unicornis $[\mathrm{P}]$ & 0.35 & 0 & 0 & 0 & \\
\hline Scolelepis squamata $[\mathrm{P}]$ & 0 & 4.13 & 35.12 & 10.87 & \\
\hline Loripes lacteus $[\mathrm{Bi}]$ & 0 & 0 & 10.33 & 0 & \\
\hline Euridice spinigera $[\mathrm{I}]$ & 2.79 & 0 & 0 & 0 & \\
\hline Euridice inermis [I] & 13.95 & 0 & 0 & 0 & \\
\hline \multicolumn{6}{|c|}{ (B) Standard hand-net collecting (individuals per unit fishing effort) } \\
\hline Euridice spinigera $[\mathrm{I}]$ & 0.52 & 0.52 & 0 & 0 & 0 \\
\hline Euridice inermis $[\mathrm{I}]$ & 1.55 & 1.04 & 7.07 & 0 & 0.52 \\
\hline Tylos sp. [I] & 2.06 & 0 & 0 & 0 & 0 \\
\hline Idotea metallica $[\mathrm{I}]$ & 0 & 0 & 0 & 0.52 & 0 \\
\hline Siriella sp. $[\mathrm{M}]$ & 0.52 & 3.84 & 4.89 & 0 & 0 \\
\hline Haplostylus sanctus $[\mathrm{M}]$ & 0 & 6.52 & 1.04 & 0 & 1.63 \\
\hline Atylus swammerdami $[\mathrm{M}]$ & 0 & 0.52 & 0 & 0 & 0 \\
\hline Parhyale eburnea $[\mathrm{A}]$ & 0 & 0 & 0 & 0 & 1.04 \\
\hline Dexamine spinosa $[\mathrm{A}]$ & 0 & 0.52 & 0 & 0 & 0 \\
\hline Pontocrates cf. altimarinus [A] & 0 & 0 & 6.52 & 0 & 0 \\
\hline Maera inaequipes $[\mathrm{A}]$ & 9.79 & 0 & 0 & 0 & 0 \\
\hline Philocheras trispinosus [Dc] & 0 & 0 & 1.04 & 0 & 0 \\
\hline
\end{tabular}

[A] Amphipoda, [Bi] Bivalvia, [Dc] Decapoda, [I] Isopoda, [M] Mysidacea and [P] Polychaeta.

Individuals of the tenebrionid genus Phaleria comprise $54.10 \%$ of all pitfall trap collections on the beaches where this technique was employed. This contrasts with the results obtained by Carpaneto and Fattorini (2001) for the beach at Castelporziano in Italy, where the tenebrionid Ammobius rufus greatly outnumbered Phaleria acuminata (48.20 and $11.82 \%$ dominance, respectively). Ammobius rufus also occurs on Maltese beaches (Table 2), however, it is mainly limited to the dunal zone, which was not sampled in the present study. The only other common animal was the polychaete Ophelia bicornis, collected only from Ramla at densities ranging from 111 to 6000 individuals $\mathrm{m}^{-2}$.

Core samples taken from the infralittoral were once again dominated by the polychaete Ophelia bicornis, together with another polychaete Scolelepis squamata. Hand-net collections in the uppermost infralittoral were dominated by mysids of the genera Siliella and Haplostylus, and by the isopod Tylos europaeus, with small numbers of amphipods and decapods.

The faunal data collected indicate that in spite of the small size of the Maltese Islands, beaches are 'compartmentalised', that is, different beaches are faunistically distinct with a large number of species that were only found on a particular beach and on no other. For example, the three beaches of Qarraba, Ghajn Tuffieha and Golden Bay are only a few hundred metres apart (Fig. 1), yet each has a fauna distinct from the others, as shown by the percentage species similarity figures. Golden Bay and Ghajn Tuffieha show a percentage faunal similarity of $20.0 \%$, while the similarities between Golden Bay and Qarraba and Ghajn Tuffieha and Qarraba are zero in both cases. All beaches with macrofauna had at least one species which was present in relatively large numbers and that was absent in the other beaches. An example is the tenebrionid Phaleria bimaculata, present in pitfall trap collections from White Tower Bay at densities of 3 individuals trap ${ }^{-1} h^{-1}$, but which was completely absent in the pitfall trap collections from other beaches. The results of the cluster analyses add further support to this idea of compartmentalisation, which also has important implications for conservation since each beach appears to be ecologically isolated and supports a more or less unique assemblage of species. This highlights the need to preserve every individual beach in the Maltese Islands.

The observed differences in faunal composition can, in some cases, be explained in terms of differences in the abiotic environment that exist between the different beaches sampled. For example, the beach at Ramla stands out from all the others; thus the pitfall trap data were significantly different from those of the other beaches studied in terms of both species composition and abundance. This is likely due to the presence of a viable sand dune system at Ramla, giving it a unique fauna. Also, sand from Ix-Xatt 1-Ahmar is significantly different $(P<0.001)$ from that at Gnejna both in terms of organic content and salinity. However, differences in the abiotic environment cannot always be used to explain the observed unique faunal composition of the beaches. 
In terms of water content, $\mathrm{pH}$ and median grain size, sand from Ix-Xatt 1-Ahmar and Gnejna was not significantly different.

Bally (1987) points out that the coarser fractions of sea-borne detritus are left on the sand at the limit of the swash zone, providing food for scavengers. This may explain the high proportion of detritivores and scavengers collected from the four beaches for which a trophic level analysis was made. According to Brown and McLachlan (1990) a high abundance of supralittoral scavengers and detritivores is related to an overall impoverished sandy beach fauna.

In comparison to other beaches, Maltese sandy beaches do indeed appear to be impoverished in terms of faunal abundances. For that part of the beach extending from the low tide mark up to the end of the supralittoral, Wooldridge, Dye, and McLachlan (1981) report macrofaunal densities on South African sandy beaches ranging from 105 to 3041 individuals $\mathrm{m}^{-2}$ and Defeo, Jaramillo, and Lyonnet (1992) recorded densities ranging from 26 to 536 individuals $\mathrm{m}^{-2}$ from Uruguay in South America. For the intertidal part of sandy beaches, Dexter (1992) reports mean densities of 241 individuals $\mathrm{m}^{-2}$ from Guinea-Bissau in Africa, 189-2461 individuals $\mathrm{m}^{-2}$ from Panama in Central America (Dexter, 1979), 941 individuals $\mathrm{m}^{-2}$ from New South Wales in Australia (Dexter, 1984), densities ranging from 76 to 2470 individuals $\mathrm{m}^{-2}$ from Portugal in Europe (Dexter, 1990), and 1347 individuals $\mathrm{m}^{-2}$ from beaches along the Sinai Peninsula in the Red Sea (Dexter, 1986/1987). In a study on the sandy beaches of the Channel Islands, USA, Dugan et al. (2000) report that in only five of the 23 beaches sampled macrofaunal abundances were less than 10,000 individuals $\mathrm{m}^{-2}$ for that part of the beach extending from the lowest edge of terrestrial vegetation to the lowest swash zone. In contrast, the beach at Ramla (Gozo), which was the richest of the Maltese beaches studied, had population densities ranging from 4 to 55 individuals $\mathrm{m}^{-2}$ for the supralittoral and mediolittoral parts of the beach during winter months. One reason for this may be that Maltese beaches are microtidal (maximum exposure during spring tides is ca $20 \mathrm{~cm}$; Drago \& Xuereb, 1993), however, these population density values are also low when compared with those from other Mediterranean sites. For example, CharfiCheikhrouha et al. (unpublished data) report amphipod densities alone as ranging from 84 to 860 individuals $\mathrm{m}^{-2}$ for the beach of Zouaraa on the northwest coast of Tunisia. For all the Maltese beaches studied taken together, the average mediolittoral and supralittoral density was 160 and 24 individuals $\mathrm{m}^{-2}$, respectively. The sandy beach at Zouaraa is $17 \mathrm{~km}$ long and bordered by a complex of sand dunes; in contrast, Maltese sandy beaches are all pocket beaches (reaching a maximum length of $1 \mathrm{~km}$ at Ghadira) with very restricted dunal development, if any. Zouaraa and Maltese beaches are therefore not really comparable, however, very few Mediterranean beaches similar to those of the Maltese Islands have been studied. Dexter (1986/1987) found population densities of 10 individuals $\mathrm{m}^{-2}$ for the intertidal zone only of the Mediterranean beaches of Egypt. However, these beaches are at the end of the strong west to east cline in declining biodiversity that exists in the Mediterranean (Pérès, 1967; Por, 1978).

When compared with data collected by other researchers working on Maltese sandy beaches and on sandy beaches in other countries, pitfall trap data collected from the supralittoral in the present study also confirm the impoverishment of Maltese sandy beaches. In fact, 28 and 23 individuals $\operatorname{trap}^{-1} \mathrm{~h}^{-1}$ were collected from Ramla in this study and by Chelazzi et al. (unpublished data), respectively. Also, 5 and 42 individuals trap ${ }^{-1} h^{-1}$ were collected from White Tower Bay in this study and by Chelazzi et al. (unpublished data), respectively. On the other hand, Colombini, Aloia, Fallaci, Pezzoli, and Chelazzi (1998) report densities of 108 individuals trap ${ }^{-1} \mathrm{~h}^{-1}$ for the coast of Somalia, using the same technique.

Maltese sandy beaches also appear to be impoverished in terms of species diversity (richness). Thus, taxa such as gastropods (e.g. Bullia), bivalves (e.g. Donax), decapods (e.g. Ocypode), mysids (e.g. Gastrosaccus) and staphylinid beetles (e.g. Bledius), generally considered to be extremely abundant on sandy beaches worldwide (Brown \& McLachlan, 1990), were entirely absent from the beaches sampled, although they or equivalent genera are common on other Mediterranean beaches (e.g. Bellan-Santini, Lacaze, \& Poizat, 1994).

The most species rich biota of sandy beaches appears to be that of the supralittoral and adlittoral zones, which consists mainly of insects and crustaceans (Brown \& McLachlan, 1990). Thus, Colombini, Chelazzi, Fallaci, and Palesse (1994) report 14 species of Tenebrionidae alone from Burano in Italy collected by pitfall traps. Only five species of tenebrioids were collected from the Maltese beaches studied here, using pitfall traps, sieving of cores samples and standard searches.

Mediolittoral faunal abundances were even lower than those reported for the supralittoral. While we collected only 105 individuals among seven species from a total cored area of $3.2 \mathrm{~m}^{2}$ ( 33 individuals $\mathrm{m}^{-2}$ ), Dexter (1986/1987) collected 159 individuals among seven species from a total sample area of $1.0 \mathrm{~m}^{2}$ from beaches along the Mediterranean coastline of Israel, which are the most depauperate in the whole Mediterranean (Por, 1978).

The physical characteristics of the sand may be important in explaining the low faunal abundances observed. Dexter (1989) reports that while faunal densities estimated by sieving on three quartz sand beaches along the Mediterranean and Red Sea coasts of Egypt ranged from 539 to 1139 individuals $\mathrm{m}^{-2}$, the 
faunal density of a nearby calcareous beach was only 66 individuals $\mathrm{m}^{-2}$. All Maltese beaches consist of limestone sand (ca 90\% carbonate; Turi, Picollo, \& Valleri, 1990), which may partly explain the low diversity found.

Another explanation may be that the sampling protocol used here was inadequate. The species-area curves all generally levelled off, suggesting this not to be the case. Additionally, in the present work, the area of supralittoral sand sieved ranged from 0.092 to $0.575 \%$ of the total beach area, and the area of sand searched ranged from 0.51 to $1.10 \%$ of the total beach, which is not an insignificant fraction, especially compared to the areas sampled in other studies. We also used a sieve size $(0.5 \mathrm{~mm}$ mesh) that is smaller than that employed in many studies (e.g. Defeo et al., 1992; Dexter, 1989, 1990, 1992) where a $1 \mathrm{~mm}$ mesh sieve was used.

The few correlations between physical parameters and faunal abundances that we found were generally inconclusive, and could not explain the impoverishment of Maltese sandy beaches. The values of sand organic content ranged from 0.039 to $0.092 \%$, which are low when compared to a mean of $0.780 \pm 0.160 \%$ for a Colombian beach studied by Griffiths and Griffiths (1983). Bally (1987) also quotes a percentage organic content value of $0.200 \%$ for the beach of Rocherpan in South Africa, which had a faunal density of 7283 individuals $\mathrm{m}^{-2}$.

Seasonal variation in faunal diversity (abundance and richness) was studied for one beach only (that at Ramla, which, however, is the one with the highest diversity locally). A significant difference was found between mean summer faunal densities estimated by sieving and mean winter faunal species densities (also estimated by sieving), with the former being $24.1 \%$ lower (mean for winter 1992 and winter 1993: 1086 individuals $\mathrm{m}^{-2}$; mean for summer 1992 and summer 1993: 482 individuals $\mathrm{m}^{-2}$ ). The higher winter values are mainly due to the presence of a large population of the polychaete Ophelia bicornis in the winter samples. Without Ophelia, the mean winter 1992/winter 1993 density becomes 111 individuals $\mathrm{m}^{-2}$ and the mean summer 1992/summer 1993 density becomes 74 individuals $\mathrm{m}^{-2}$. Therefore, it might be that the observed impoverishment of Maltese beaches is related to seasonally biased sampling, since apart from Ramla, the other beaches were sampled only in summer. However, it is significant that $O$. bicornis was only found at Ramla and not at any of the other beaches, not even at very low population densities.

Carpaneto and Fattorini (2001) report winter and summer decreases in the tenebrionid beetle assemblage at Castelporziano in Italy. A similar pattern was reported for Saudi Arabia by Aldryhim, Mills, and Aldawood (1992), where summer and winter disappearances were correlated with temperature extremes. This conforms to the general pattern of abundance fluctuations in terrestrial arthropod populations in southern
Mediterranean coastal areas as outlined by Dajoz (1987) and Hornung and Warburg (1995). Therefore, even though seasonal variability is probably not the only explanation, this factor requires further study. Marine pollution can probably also be dismissed as a contributing factor to the observed low diversity. Maltese waters have not yet been exposed to any massive oil pollution accident and chronic pollution by oil and petroleum products is only important in harbours and yacht marinas (Axiak et al., 1999), which are not present in the vicinity of the beaches studied.

Due to the intense use of nearly all beaches, human disturbance might be an important factor contributing to the low faunal diversities reported. Surprisingly however, although human occupancy rates for the different beaches studied were significantly different from each other, the faunal diversities as estimated by three different techniques were not significantly different in either abundance or species richness for these beaches for any of the three techniques.

This only leaves biological factors as a possible explanation for the observed patterns. One factor that may explain why certain species are missing could be a lack of recruitment. Malta is approximately $92 \mathrm{~km}$ from the nearest land - the island of Sicily - and so is physically isolated from the nearest populations of beach biota. However, the compartmentalisation of the beach biota suggests that even dispersal between beaches on the same coast may be limited. These aspects need further study.

\section{Acknowledgements}

Some of this work was carried out as part of the MECO project (Bases for the Integrated Sustainable Management of Mediterranean Sensitive Coastal Ecosystems) funded by the European Commission under its 'Co-operation with the Third Mediterranean Countries and International Organizations' (Contract No. ERB IC 18-C198-0270). We are grateful to the coordinator of MECO, Professor Felicita Scapini (CoNISMa, Italy) and to the Malta coordinator of the project, Louis F. Cassar (Foundation for International Studies) for financial and other help received. Additional funding was provided by research grants from the University of Malta to PJS, for which we are also grateful. We thank Joseph A. Borg, Stephen Cachia, David Dandria, Edwin Lanfranco and Stephen Schembri (all at the University of Malta), and Dr Lorenzo Chelazzi, Dr Isabella Colombini, Dr Mario Fallaci, Dr D. Benvenuti and Dr G. Messana (all from the Centro di Studio per la Faunistica ed Ecologia Tropicali del C.N.R, Firenze) for the identification of specimens and much other help. Thanks are also due to Joseph Debono, Diane Micallef, Miraine Rizzo and Mario Saliba for help with the fieldwork and the laboratory analyses. 


\section{References}

Abele, L. G. (1976). Comparative species composition and relative abundance of decapod crustaceans in marine sediments. Marine Biology 38, 263-278.

Aldryhim, Y. N., Mills, C. W., \& Aldawood, A. S. (1992). Ecological distribution and seasonality of darkling beetles (Coleoptera: Tenebrionidae) in the central region of Saudi Arabia. Journal of Arid Environments 23, 415-422.

Axiak, V., Gauci, V., Mallia, A., Mallia, E. A., Schembri, P. J., \& Vella, A. J. (1999). State of the environment summary report for Malta 1998 (130 pp.). Floriana, Malta: Environment Protection Department, Ministry for the Environment.

Bally, R. (1987). The ecology of sandy beaches of the Benguela ecosystem. South African Journal of Marine Science 5, 759-770.

Bellan-Santini, D., Lacaze, J. C., \& Poizat, C. (1994). Les biocénoses marines et littorales de Méditerranée, synthèse, menaces et perspectives (246 pp.). Paris: Muséum National D'Histoire Naturelle.

Brown, A. C., \& McLachlan, A. (1990). Ecology of sandy shores. Amsterdam: Elsevier.

Buchanan, J. B. (1984). Sediments. In N. A. Holme, \& A. D. McIntyre (Eds.), Methods for the study of marine benthos (pp. 30-52). Oxford: Blackwell.

Carpaneto, G. M., \& Fattorini, S. (2001). Spatial and seasonal organisation of a darkling beetle (Coleoptera, Tenebrionidae) community inhabiting a Mediterranean coastal dune system. Italian Journal of Zoology 68, 207-214.

Charfi-Cheikhrouha, F., Bouslama, M. F., \& ElGtari, M. (2001). Factors influencing the seasonal distribution of Talitrus saltator and Talorchestia brito of Zouraa sandy beach (North-Western Tunisia). In Beaches- what future? An integrated approach to the ecology and evolution of beaches and sand dunes. International Workshop Florence, Italy-18-23 October 2001. Dipartimento di Biologia Animale e Genetica 'Leo Pardi', Università di Firenze/ Centro di Studio per la Faunistica ed Ecologia Tropicale del CNR/ European Commission (Abstracts Volume p. 24).

Clarke, K. R., \& Warwick, R. M. (1994). Change in marine communities: An approach to statistical analysis and interpretation (144 pp.). Plymouth: Natural Environment Research Council.

Colombini, I., Aloia, A., Fallaci, M., Pezzoli, G., \& Chelazzi, L. (1998). Spatial use of an equatorial coastal system (East Africa) by an arthropod community in relation to periodically varying environmental conditions. Estuarine, Coastal and Marine Science 47, 633-647.

Colombini, I., Chelazzi, L., Fallaci, M., \& Palesse, L. (1994). Zonation and surface activity of some tenebrionid beetles living on a Mediterranean sandy beach. Journal of Arid Environments 28, 215-230.

Colombini, I., Fallaci, M., Milanesi, F., Scapini, F., \& Chelazzi, L. (2003). Comparative diversity analysis in sandy littoral ecosystems of the Western Mediterranean. Estuarine, Coastal and Shelf Science D311.

Dajoz, R. (1987). Les coleopteres Carabidae et Tenebrionidae de quelques milieux littoraux de Grece meridionale. Cahiers Naturels $43,1-16$.

Defeo, O., Jaramillo, E., \& Lyonnet, A. (1992). Community structure and intertidal zonation of the macroinfauna of the Atlantic coast of Uruguay. Journal of Coastal Research 8, 830-839.

Dexter, D. M. (1979). Community structure and seasonal variation in intertidal Panamanian sandy beaches. Estuarine and Coastal Marine Science 9, 543-558.
Dexter, D. M. (1984). Temporal and spatial variability in the community structure of the fauna of four sandy beaches in south-east New South Wales. Australian Journal of Marine and Freshwater Research 35, 663-672.

Dexter, D. M. (1986/1987). Sandy beach fauna of Mediterranean and Red Sea coastlines of Israel and the Sinai Peninsula. Israel Journal of Zoology 34, 125-138.

Dexter, D. M. (1989). The sandy beach fauna of Egypt. Estuarine and Coastal Marine Science 29, 261-271.

Dexter, D. M. (1990). The effect of exposure and seasonality on sandy beach community structure in Portugal. Ciencia Biologica 10, $31-50$.

Dexter, D. M. (1992). The sandy beach fauna of Praia de Bruce, Bubaque, Guinea-Bissau. Bolletino del Instituto Nacional de Investimento della Pescas 17, 97-101.

Dixon, W. J. (Ed.). (1988). BMDP statistical software manual. Vols. I and II (513 pp.). Berkeley: University of California Press.

Drago, A. F., \& Xuereb, A. (1993). Tide tables 1993, Grand Harbour, Malta (43 pp.). Malta: Malta Maritime Authority and Malta Council for Science and Technology.

Dugan, J. E., Hubbard, D. M., Martin, D. L., Engle, J. M., Richards, D. M., Davis, G. E., Lafferty, K. E., \& Ambrose, R. F. (2000). Macrofauna communities on exposed sandy beaches on the southern California mainland and Channel Islands. Fifth California Islands Symposium (pp. 339-346). OCS Study, MMS 990038 .

Eifion Jones, W. (1980). Field teaching methods in shore ecology. In W. F. Farnham, D. E. G. Irvine, \& J. H. Price (Eds.), The shore environment, Methods Vol. 1 (pp. 19-44). London: Academic Press.

Griffiths, C. L., \& Griffiths, R. J. (1983). Biology and distribution of the littoral rove beetle Psamathobledius punctatissimus Le Conte (Coeloptera Staphylinidae). Hydrobiologia 101, 203-214.

Hornung, E., \& Warburg, M. R. (1995). Seasonal changes in the distribution and abundance of isopod species in different habitats within the Mediterranean region of northern Israel. Acta Oecologica 16, 431-445.

Marques, J. C., Bouslama, M. F., Charfi-Cheikhrouha, F., Chelazzi, L., Colombini, I., ElGtari, M., Fallaci, M., Goncalves, S. C., Pardal, M. A., \& Scapini, F. (2003). Biology. Estuarine, Coastal and Shelf Science D318.

McLachlan, A. (1991). Ecology of coastal dune fauna. Journal of Arid Environments 21, 229-243.

Morgans, J. F. C. (1956). Notes on the analysis of shallow-water substrata. Journal of Animal Ecology 25, 367-387.

Norusis, M. J. (1993). SPSS for windows: Professional statistics, release 6.0 (84 pp.). New York: Prentice-Hall.

Pérès, J. M. (1967). The Mediterranean benthos. Oceanography and Marine Biology an Annual Review 5, 449-533.

Por, F. D. (1978). Lessepsian migration: The influx of Red Sea biota into the Mediterranean by way of the Suez Canal (228 pp.). Berlin: Springer.

Thomas, M. L. H. (1986). A physically derived exposure index for marine shorelines. Ophelia 25, 1-13.

Turi, A., Picollo, M., \& Valleri, G. (1990). Mineralogy and the origin of the carbonate beach sediments of Malta and Gozo, Maltese Islands. Bollettino della Societa Geologica Italiana 109 , 367-374.

Wooldridge, T., Dye, A. H., \& McLachlan, A. (1981). The ecology of sandy beaches in Transkei. South African Journal of Zoology 16 , 210-218. 